\title{
Searching the Path of Juvenile Legal Education
}

\author{
Zhijian Wang and Liuyu Lin
}

\author{
Keywords: Adolescents; The rule of law; Education; Path
}

\begin{abstract}
Juvenile law education is a systematic project related to the long-term stability of the country, in addition to the education of legal knowledge of young people, it should start from three paths: the schools education, family education, and social education. Then we can explore an education road consists of a legal education of young people, the concept of law education, the rule of law awareness education and the rule of law faith.

The thought of China named "managed by man" has ruled the feudal society for thousands of years. It hindered the construction of social democracy and the rule of law seriously, even in today's society of socialist democracy and the increasing rule of law, we can also see the residual thought, "managed by man". In order to eliminate the thought of "managed by man" thoroughly, promote the rule of law comprehensively, the construct socialist country under the rule of law, the Party's 15th national congress to put forward the " rule of law, build a socialist country under the rule of law" major strategic tasks formally. The fourth plenary session of the eighteenth central Committee of the party hand out a rule clearly, that is," the rule of law education into the national education system, to start from the young people, to set up the rule of law knowledge curriculum in primary and middle schools ".The 19th national congress of the communist party of China stressed the need to strengthen the law popularization, improve the legal literacy of the whole nation, build a socialist culture of the rule of law, establish the concept of the rule of law, the supremacy of the constitution and the law, equality before the law. Thus, on the basis of comprehensively promoting the rule of law, the construction of socialist rule of law in our country, we have explored a long-term mechanism to realize the construction of socialist rule of law, which is based on the education of juvenile rule of law, and follow a gradual, systematic and effective, solid and powerful way of education gradually.
\end{abstract}

\section{The Rule of Law Education for Young People Should be led by School Education}

School is the cradle of the growth of young people. The level of legal education on campus is related to the formation of juvenile awareness of the rule of law and the concept of the rule of law, but also related to the concept of the rule of law and the rule of law belief of young people. For that, the importance of the rule of law education for young people, we should start from the following aspects:

First, on specialized courses. In our country, the rule of law education has already existed in the national education system, not only started the course named" knowledge of legal" in junior high school, but also opened the "ideological and moral cultivation and legal basis course" in the university. However, these courses are mainly for the teaching of legal knowledge, and under the guidance of examination-oriented education, it is difficult to achieve the popularization of juvenile legal knowledge, as for the concept of the rule of law and belief is hard to reach. For this reason, the school's special curriculum, the rule of law education and moral education should be closely combined, dealing with the different stages of education to develop different specialized courses of law education. During the junior high school period, the rule of law education should be set up as special courses, paid attention to the content of the rule of law education, focused on teaching legal knowledge. So that students can know about the law; During high school, in view of the reality of the college entrance examination education, the rule of law education should be regard as an important part of ideological and political courses to increase the depth and breadth of knowledge of the rule of law and strengthen the theoretical integration of knowledge of the rule of law and ideological and political knowledge; During higher education, the rule of law education should be set as a compulsory course or basic course to increase the rule of law education class and focus on 
the realization of the transformation of young people from " legal education" to " rule of law education".

Second, on teaching methods. At present, the rule of law education for young people mainly adopts to the teaching method which spoon-fed teaching method for non-legal professional students, especially primary and secondary school students who can only master the basic legal knowledge. It is difficult to be familiar with the content of the rule of law, the rule of law concept and belief in the rule of law more impossible to talk about. In this regard, the teaching method of juvenile law education, in the primary and secondary school stage, on the basis of teaching the knowledge of the rule of law, should take the story teaching method and the real cases of the rule of law around primary and secondary school students into the classroom teaching in an easy-to-understand way to teach students. In the stage of higher education, due to the improvement of college students' social cognitive ability, in the way of legal education, in addition to strengthening the theoretical education, but also we should pay attention to students' legal education practicing education. It can take scenario simulation, role play, case study, legal debate, practice investigation and other teaching methods. By inviting relevant lawyers, judges, police and other cases of the rule of law publicity and education, so that students are deeply aware of the seriousness of the law and the importance of the rule of law. By organizing students to participate in the court trial and visiting the prison on the spot to strengthen the legal education of students with real on-site experience, guiding students to realize the change from " passive learning" to " autonomous learning", in order to realize the students' rule of law concept and rule of law belief.

Third, on the rule of law education teachers for young people. Recently, the task of juvenile legal education is mainly carried out by ideological and political teachers. The urgent shortage of professional teachers in legal education seriously affects the effect of juvenile legal education. Therefore, to constructa professional youth legal education team is to ensure the smooth development of juvenile legal education work premise and guarantee. On the one hand, to strengthen the construction of teaching teachers in school about law education. The main body of the youth's legal education is the ideological and political theory course teachers, which shoulder to carry out legal education for young people, armed young people with the new era of the latest achievements of the socialist theory of the rule of law with Chinese characteristics. And help them establish the correct concept of the rule of law, train young people's awareness of the rule of law and the spirit of the rule of law. In addition to the ideological and political theory course teachers, it can be recommended with legal professional knowledge and rich practical experience of professionals, such as public security department professionals, law, political science and law school teachers, etc. Aim to enrich the juvenile law education team. On the other hand, we strengthen the construction of the supervision team of school law education in order to ensure the smooth development of juvenile law education work. We must set up a supervision team under the leadership of the school, under the guidance, supervision and coordination of the leadership of the school, the supervision personnel to carry out their duties, to ensure that the teachers fulfill their duties to complete the work of juvenile law education.

Fourth, on the construction of campus legal culture. On the basis of imparting knowledge of the rule of law, schools should create a strong legal campus culture atmosphere, the spirit of the rule of law, the concept of the rule of law and the belief in the rule of law to improve the school education, manage and service of all aspects. Schools should make full use of the class group, student associations, party team activities and other carriers, make full use of national defense education day, international drug control day, consumer rights day, national constitution day and other festivals, in the form of knowledge contest, speech contest, debate, volunteer service, to carry out safety education, national defense education, traffic safety education, drug education and other special education and cultural activities, in order to guide young people to participate in and experience, in a variety of forms, rich and colorful, loved by the campus culture to attract young people into the atmosphere of law education. 


\section{Second, the Rule of law Education for Young People Should be based on Family Education}

During his meeting with the first representatives of the national civilized family, general secretary Xi Jinping stressed that the family is the first classroom in life and the parents are the first teachers for the children. In this regard, to strengthen the rule of law education for young people, we must take family education as the basis and pay attention to family construction, the family itself, family education and family style.

First, family education should enhance parents' awareness of the rule of law. As teenagers in primary and secondary schools, the concept of the rule of law is in the embryonic stage, but family education can play a subtle impact. Thus, as parents, we must know the law, understand the law, obey the law. Only parents know the law in daily life, with the law to protect their legitimate rights and interests, can we consciously abide by the law to be a qualified law-abiding citizens. Only in this way, the rule of law education of young people can lead to the parents as examples, subtly affect the children's awareness of the rule of law to cultivate children's awareness of the rule of law and play a very important role.

Second, we should pay attention to the construction of harmonious family atmosphere on family education. In today's highly developed network information, as a growing stage of young people, facing the impact of negative information from all directions, it is easy to lead to confusion among young people and accept the wrong information astray. In this regard, as parents to create a free, democratic and equal family atmosphere, guiding young people to actively participate in the construction of the family andform a good family communication atmosphere. Only in this way, parents in urging the correction of juvenile delinquency, prevent illegal behavior, correctly guide the young people to establish the concept of right and wrong, law and discipline, the rule of law education, in order to avoid adolescent resistance to achieve the purpose of juvenile law education effectively.

Third, family education should pay attention to the discipline of young people. Teenagers are the key period for the formation of outlook on life, values and world outlook, and also the best period for legal education. Parental discipline of young people, it is related to the healthy growth of young people. It can become useful to the country and the people. Looking at the young people astray behind the illegal crime, the vast majority of families are inseparable from the neglect of youth discipline, resulting in parents do not understand the growth of children, inadequate education, management is not timely. In this regard, parents should always pay attention to the growth of young people, in view of the problems of young people, to timely find, education, correction to help them take the first step of life.

\section{The Rule of Law Education for Young People Rely on Social Education}

The ultimate goal of family and school education for teenagers' legal education ensures that teenagers can abide by the law and establish the correct concept of the rule of law and belief in the rule of law after entering the society. However, the complexity and diversity of society determine that the rule of law education for young people is not over, and social education still has a long way to go.

First, social education is inseparable from the participation of state organs and social forces. As the successor of the socialist cause, whether the rule of law education is in place or not, it is related to the implementation of the country's comprehensive rule of law, and even related to the country's long-term stability. In this regard, the state organs and social forces should fully support and participate in the work of the rule of law education for young people to protect the rule of law education for young people. As a public security law and other state organs, strictly handle cases according to law, ensure judicial fairness, justice and openness, create a good social environment for the rule of law, so that young people not only know the law, understand the law, law - abiding, and believe in the rule of law, advocate the rule of law, believe in the rule of law; As a bar association, the relevant administrative departments, actively carry out publicity and education of the rule of law, strengthen the cooperation with the school of law education, provide schools with 
the corresponding legal education resources and practical opportunities; As a news publishing house, radio and television, network and other media, we should strictly grasp the publicity, give full play to the positive function of the media in the formation and guidance of public opinion in juvenile law education to ensure that the media always highlight the theme, always adhere to the rule of law education as the goal, creation and dissemination of works suitable for juvenile law education, firmly grasp the ideological education of young people, the formation of the rule of law education of social cohesion and a good atmosphere.

Second, social education is inseparable from social practice education. The legal education of teenagers should not only stay in the teaching of theoretical knowledge, but also pay attention to the organic combination of theory and practice. In this regard, education departments and schools at all levels should attach great importance to the rule of law and social practice education of young people, actively in the public security law, law firm, community and other departments to build the practice of juvenile law education base and make full use of social resources, arrange young people in the real practice of the rule of law in the practice of learning, realize the rule of law education of young people from learning to knowing the law, understanding the law, abiding by the law, from the practice of middle school law, usage, faith law.

Third, social education is inseparable from the development and utilization of network resources. In the internet age, all kinds of information are mixed with each other, and all kinds of bad information are filled with the network of teenagers, which seriously affect the healthy growth of teenagers. Social administrative departments and schools should strictly shut down the network, purify the network environment, make full use of all kinds of network advantages to strengthen the rule of law education and publicity, enhance the appeal of network rule of law education to young people in order to occupy the network positions of young people. On the one hand, the school uses the official wechat public platform or online official forum, the establishment of juvenile law education layout through the regular release of the rule of law education related theory, typical cases, recording the rule of law education video open classes for students to watch and learn. On the other hand, we should encourage relevant teachers to use the classroom, micro blog, blog and other ways to share views on the rule of law with college students, and actively guide the concept of the rule of law of college students.

Teenagers are the future of the nation. It is the hope of the country. In the stage of basic education strengthen the rule of law education. It conducives to the formation and development of healthy personality of teenagers and conducive to the smooth development of the country's comprehensive rule of law, It conducives to the country's long-term stability. In this regard, the rule of law education for young people must adhere to the school education as the leading, family education as the basis, relying on social education to achieve a close combination between the three, mutual cooperation, mutual promotion, co-management of juvenile law education situation.

\section{References}

[1] Ministry of education, Ministry of justice, the national legal office. juvenile law education program [ n ]. 2016 - $07-04$.

[2] Sun Dongzhe. Youth " legal education" to " legal education" concept transformation and system construction [ j ]. juvenile delinquency, 2016 ( 5 ).

[3] He Liuming. To strengthen the rule of law publicity and education of youth exploration and thinking [ j ]. Chinese justice, 2015 ( 2 ).

[4] Wang Shuangqun. Rule of law education and moral education connotation and significance [ $\mathrm{j}$ ]. theory monthly, 2006 ( 7 ).

[5] Yin Xiaohu. "X second generation" crime and youth civic education [ $\mathrm{j}]$. contemporary youth research, 2013 ( 6 ).

[6] Xie Youping. Multi - perspective of the rule of law in the United States youth education: ways, strategies and inspiration [ j ]. juvenile delinquency, 2007 ( 3 ). 